\title{
Development of Android Application based on Holland's Theory of Individual Student Planning
}

\author{
Agus Ria Kumara \\ Ahmad Dahlan University, \\ Yogyakarta, Indonesia \\ agus.kumara@bk.uad.ac.id \\ Budi Astuti \\ Universitas Negeri Yogyakarta, \\ Yogyakarta, Indonesia \\ budi_astuti@uny.ac.id
}

\author{
Caraka Putra Bhakti \\ Ahmad Dahlan University, \\ Yogyakarta, Indonesia \\ caraka.pb@bk.uad.ac.id \\ Suwarjo \\ Universitas Negeri Yogyakarta \\ Yogyakarta, Indonesia \\ suwarjo@uny.ac.id
}

\author{
M. Alfarizqi Nizamuddin Ghiffari \\ Ahmad Dahlan University, \\ Yogyakarta, Indonesia \\ muhammad1500001138@webmail \\ .uad.ac.id
}

\author{
Fathia Irbati Ammattulloh \\ Ahmad Dahlan University, \\ Yogyakarta, Indonesia \\ fathia@gmail.com
}

\begin{abstract}
The purpose of this study to develop a theory Holland used as individual student planning in order to assist students in career planning by android application. Career is something important for students. The career of the students will determine the future of the students' future. The importance of career planning as mature as possible, resulting in career planning need to pay attention to a variety of things, such as the characteristics of the individual, and the ability of others. It is closely related to the theory of Holland. This theory says humans in determining the views of the characteristics of her career include: Realistic, Investigative, Artistic, Social, Enterprising, Conventional. The career planning can be applied in the Individual Student Planning which is one of the services in guidance and counselling. Individual student planning is one of the services provided to students to develop academic life, career, social and others. Following the development of the times, the provision of individualized student planning can be applied in technology. The method used is research and Development, which developed the Android- application based on Holland theory. It is expected that students will be able to plan his career according to the characteristics and personality.
\end{abstract}

Keywords- Individual Student Planning, Holland's Theory, Career, Applications Android

\section{INTRODUCTION}

Career is something that is very fundamental in the community. The importance of having a career man will determine the success and life in the future. Of course, have a good career and optimal require careful career planning and it started human teenager. This is because when the adolescent humans have been talking about the future. Elizabeth B. Hurlock [6] Adolescents begin to reveal their future seriously. Adolescents begin to pay greater attention to the various fields of life to be lived as adults in the future [8]. From these statements, since human teens start thinking about the future of jobs or careers when will grow up.

Plan and develop a career since his teens would be a phenomenon that will continue in human life. It because as a teenager, there are some tasks that need to be met by the development of a teenager at the time. Career and talent development for adolescents involves learning processes related to understanding one's own interests and abilities and interacting with the world of work overtime [12]. Together with a statement Ginzberg, et al [8] divides the adolescent developmental tasks that need to be prepared in a career that is a teenager entered a stage in which they already know better interests, abilities, and values that would like to pursue. Thus, career planning and career development these teenagers need to be prepared so that teens can meet its development needs. Surely in planning and teens develop a career there are some things that need to be learned by teens themselves about their ability to him. According to Gysbers [7] identified the following behaviours and skills for career readiness: "(a) social competence, (b) diversity skills, (c) positive work habits, (d) personal qualities, (e) personality and emotional states, and (f) entrepreneurship". These components need to be considered and to be prepared by to assist students in career planning optimally. Based on what was stated earlier, an important component to be developed and planned are qualities, personality and skills.

In this regard, of course in career planning, there are various theories which can be used. One theory that can be used in a student's career plan view of the personality, characteristics, abilities and skills, as well as the quality of the self, is the theory of Holland. Holland theory is a theory that said that person's job can be determined and planned based on the characteristics and abilities. Holland Believes that one's selection of an occupation is an expression of one's personality [10]. Holland theorized that humans are more dominant in one or more personality than six personalities formulated by Holland. From here, Holland's theory can be applied to students' career planning. Of course, in career planning, it can be done in various ways, one of them through school. At school, school counsellor or teacher guidance and counselling have an important role in helping students plan their careers and develop. As part of the preparation of students to be career ready, professional school counsellors play a key role in the 
guidance and services offered to assist students [1]. Obviously, this becomes an important task for school counsellors to be able to accompany their students to be able to plan an optimal career.

School counsellors have a wide range of services which can be used in developing the potential of students, especially in the field of career. Services in comprehensive counselling services, there are 4 components: 1) Core Curriculum, 2) Individual Planning Services Specialization and, 3) the service is responsive, 4) Support system [4]. These services can be used to develop and assist students in planning his future career.

From some of the services that can be used, individually or individual student planning have in helping students to plan his career. Individual student planning been because have the specific objectives can plan a career of students, academic or otherwise. Thus, individual student planning chose to help students plan his career. Of course, to make it easier for school counsellors to provide services, the need for innovation in providing individual student planning. Technologies enable people to do various things. In this study, we tried to make an android application which can be used to help students planning a career using Holland's theory.

\section{RESEARCH METHOD}

The method used is Research and Development. This research doing in several stages. In this study, we are still in the stage of the design and concept. Then, after making the design and concept, we will resume at the stage where our application development using an application android studio to create applications. Then we do early trials and mass trials continue.

From this study is based on a review of literature which is obtained from journals, books and some other literature. In addition, we conducted an analysis of data collected from the literature. From here look for a correlation between every aspect and indicators.

\section{A. Individual Student Planning}

Developing a student's career certainly can be done in various ways. guidance and counselling conducted at the school became one of the alternatives in developing careers and assist students in career planning students. In a comprehensive guidance and counselling, offering a wide range of services provided to students. In a comprehensive guidance and counselling services in four service components are 1) Basic Service, 2) Individual Planning Services Specialization and, 3) The service is responsive, 4) Support system [4]. Of the various existing services, specialization and individual planning or individual student planning to become one of the services that can be given guidance and counselling teachers or school counsellors in helping students plan and develop his career.

Individual student planning is one of the services which help students plan objectives and measures in the future. Student learning plans, Often Referred to as "roadmaps," assists students in creating courses of study that are aligned with high school graduation requirements, personal interests, and individually defined career goals [7]. This was confirmed by ASCA [3] which says Individual Student Planning (ISP) is Sessions in the which school counsellors focus on education planning, Including, but not limited to, academic planning, course enrolment, graduation planning, developing individual learning plans, etc. Thus, the planned measures students will be questions for students to be able to achieve its goals and objectives related to academic, career and life goals of the students themselves.

Individual student planning is a service provided to the individual student. in the planning of individual students, there are a few things to note. Individual student planning Working with one student to analyse and Evaluate individual abilities, skills and achievement. Test information may provide the basis for immediate and long-range plans [3]. From some of these, students will learn what the potential in him as the basis for planning in their lives. Students use plans to reflect upon and document Reviews their skills, hobbies, accomplishments, academic record, personal goals, career interests and other information relevant to them as individuals [7]. Thus, from the study and reflect on what is the potential in students, what has been done and so will be the basis for determining the pace and life planning.

\section{B. Holland Theory}

Holland Theory is one theory that is still used in planning one's career to date. In this theory says that in the career planning depends on the character and personality of the man himself. Holland Believes that one's selection of an occupation is an expression of one's personality [10]. This was continued in the opinion According to Holland [11] says that If people's personality types and their occupation fit each other, employees' function will rise. When the job is selected in accordance with the personality of a person then that person will develop and optimally in the work.

Relating to personality, formulate Holland there are six personalities or RIASEC in determining a person's career. The theory's core idea is six basic personality types: Realistic, Investigative, Artistic, Social, Enterprising, and Conventional (commonly abbreviated with the acronym RIASEC) [9],[5]. In planning a career or a job, everyone has the personality of a combination of the sixth, and the dominant personality would lead to a specific job or career. Each personality has their own specification. According to Holland [10] each has a personality of their own specification as in the following table: 
TABLE I. DESCRIPTION OF SIX CHARACTER HOLLAND'S THEORY

\begin{tabular}{|c|c|}
\hline Personalities & Description \\
\hline Realistic (R) & $\begin{array}{l}\text { Likes to work with animals, tools, or } \\
\text { machines; generally, avoids social activities, } \\
\text { such as teaching, healing, and informing } \\
\text { others; has good skills in working with tools, } \\
\text { mechanical or electrical drawings, } \\
\text { machines, or plants and animals; values } \\
\text { practical things one can see, touch, and use, } \\
\text { such as plants and animals, tools, equipment, } \\
\text { or machines; and sees self as practical, } \\
\text { mechanical, and realistic. }\end{array}$ \\
\hline $\begin{array}{l}\text { Investigative } \\
\text { (I) }\end{array}$ & $\begin{array}{l}\text { Likes to study and solve math or science } \\
\text { problems; generally, avoids leading, selling, } \\
\text { or persuading people; is good at } \\
\text { understanding and solving science and math } \\
\text { problems; values science; and sees self as } \\
\text { precise, scientific, and intellectual. }\end{array}$ \\
\hline Artistic (A) & $\begin{array}{l}\text { Likes to do creative activities, such as art, } \\
\text { drama, crafts, dance, music, or creative } \\
\text { writing; generally avoids highly ordered or } \\
\text { repetitive activities; has good artistic } \\
\text { abilities in creative writing, drama, crafts, } \\
\text { music, or art; values the creative arts and } \\
\text { likes drama, music, art, or the works of } \\
\text { creative writers; and sees self as } \\
\text { expressive, original, and independent. }\end{array}$ \\
\hline Social (S) & $\begin{array}{l}\text { Likes to do things to help people, such as } \\
\text { teaching, nursing, giving first aid, or } \\
\text { providing information; generally, avoids } \\
\text { using machines, tools, or animals to achieve } \\
\text { a goal; is good at teaching, counselling, } \\
\text { nursing, or giving information; values } \\
\text { helping people and solving social problems; } \\
\text { and sees self as helpful, friendly, and } \\
\text { trustworthy. }\end{array}$ \\
\hline $\begin{array}{l}\text { Enterprising } \\
\text { (E) }\end{array}$ & $\begin{array}{l}\text { Likes to lead and persuade people and to sell } \\
\text { things and ideas; is good at leading people } \\
\text { and selling } \\
\text { things or ideas; values success in politics, } \\
\text { leadership, or business; and sees self as } \\
\text { energetic, ambitious, and sociable. }\end{array}$ \\
\hline $\begin{array}{l}\text { Conventional } \\
\text { (C) }\end{array}$ & $\begin{array}{l}\text { Likes to work with numbers, records, or } \\
\text { machines in a set, orderly way; generally, } \\
\text { avoids ambiguous, unstructured activities; is } \\
\text { good at working with written records and } \\
\text { numbers in a systematic, orderly way; } \\
\text { values success in business; and sees self as } \\
\text { orderly and good at following a set plan. }\end{array}$ \\
\hline
\end{tabular}

Nonetheless, every person sometimes has not only one characteristic. Holland assumes that each person can have more than one characteristic. Yet to be seen which one is dominant. Many individuals have a dominant type they most closely resemble that plus one or more additional types (called subtypes) that They also resemble some degree [5]. Thus, each person can have not only one characteristic but may have two or more, but it remains to be seen where the dominant characteristic of every human being.

There are some things that need to be considered in planning and career decide using Holland's theory. Four important constructs related to the predictions are congruence, differentiation, consistency, and identity [5]:

- Congruence: people seek environments that fit well with their personalities,

- Differentiation: Holland used the term differentiation to describe the degree to which a person or environment is clearly defined with respect to the RIASEC types.
- Consistency: Consistency is positively associated with ease of career decision making. People with highly inconsistent personalities may be more challenged when attempting to

find highly congruent environments.

- Identity: Identity refers to the degree to which a person has "a clear and stable picture of one's goals, interests, and talents

Thus, these things need to be considered in determining a person's career using Holland. Holland's theory is currently in search for what becomes of human characteristics, has provided the search tools easier. Self-Directed Search, a data collection tool in determining the dominant characteristics of a person. This will be very helpful in determining the characteristics of a person and will be very helpful in determining the person's career.

Self-Directed Search form questionnaire which contains a declaration which is given to someone. The statement filled in accordance with the conditions and the situation of these people, whether in accordance with that person or not. Here are a few items in the questionnaire statement Self Directed Search [2]:

\begin{tabular}{|c|c|}
\hline Personalities & Questioner \\
\hline Realistic (R) & $\begin{array}{l}\text { - } \quad \text { Working with things, machines and tools } \\
\text { - } \quad \text { Working with plants or animals } \\
\text { - } \text { Working outdoors and generally } \\
\text { - } \quad \text { Woeping fit } \\
\text { something with my hand in building } \\
\text { - } \quad \text { Fixing machine } \\
\text { - Reading plans and engineering } \\
\text { - } \text { Arawings } \\
\text { applying the theory in a practical way } \\
\text { and to do it with his own hands }\end{array}$ \\
\hline $\begin{array}{l}\text { Investigative } \\
\text { (I) }\end{array}$ & 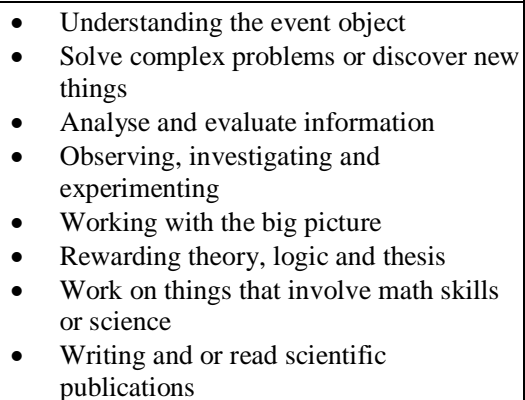 \\
\hline Artistic (A) & $\begin{array}{l}\text { - Using the skills of artistic Me (music, art, } \\
\text { performance, movies, electronic design } \\
\text { or product) } \\
\text { - } \quad \text { Working with my imagination } \\
\text { - } \quad \text { Reading and writing literature } \\
\text { - } \quad \text { Analysis and appreciate works of art or } \\
\text { work in the creative industries }\end{array}$ \\
\hline Social (S) & $\begin{array}{l}\text { - } \quad \text { Work with others } \\
\text { - } \quad \text { Working in the industry who have a goal } \\
\text { - } \quad \text { Onvolved in community activities } \\
\text { - } \quad \text { Analysis how people work and think and } \\
\text { what motivates people to work } \\
\text { - Helping others } \\
\text { - Helping others learn, develop or enhance } \\
\text { - } \quad \text { Or improve health or situation } \\
\text { Getting people to work together and or } \\
\text { using the skills of diplomacy or negotiate }\end{array}$ \\
\hline
\end{tabular}




\begin{tabular}{|c|c|}
\hline $\begin{array}{l}\text { Enterprising } \\
\text { (E) }\end{array}$ & \begin{tabular}{ll|} 
- & Work with challenges influence and \\
persuade people to \\
-
\end{tabular} \\
\hline $\begin{array}{l}\text { Conventional } \\
\text { (C) }\end{array}$ & $\begin{array}{l}\text { - Working towards goals and motivated by } \\
\text { a sense of accomplishment itself business } \\
\text { - Sales (sales) or business development } \\
\text { and public speaking or debating } \\
\text { - Willing to take calculated risks } \\
\text { - Following the process and meet clear } \\
\text { standards } \\
\text { - Working on the Space } \\
\text { - Operates office machines } \\
\text { - Oriented task or role, task-oriented that } \\
\text { debating and time efficient } \\
\text { - Shows a tendency on the things that } \\
\text { regularly } \\
\text { work where I can use my skills in } \\
\text { organizing and or administer } \\
\text { - Working with the data, finance, } \\
\text { numbers and system } \\
\text { Maintaining and updating records and } \\
\text { check for errors } \\
\text { - Working on projects that are generally } \\
\text { free of risk }\end{array}$ \\
\hline
\end{tabular}

A statement in questioner can be developed and can be used as an assessment tool in knowing the personality of each person. From here will be seen how the number of statements selected from each personality. The statement is the most preferred of one indicator can be a picture of the personality of the individual in question.

\section{DISCUSSION}

\section{A. Holland Theory Application}

Individual student planning is one way to help students plan a future career. As one of guidance and counselling services in a comprehensive, individualized student planning will be given to students in planning every aspect of life one career. certainly, in the individual student planning need approaches that can develop the student's career, one of which is the theory of Holland.

Using Holland theory, students today need to plan his career with the optimal based on six personalities there. Students can do assessments and will find what the student will know the advantages and characteristics. It is a cornerstone in determining students' future career.

Holland's theory can be Individual Student Planning, which Holland theory this will really help a school counsellor or teacher guidance and counselling to help students determine future careers. Through the determination of the basic concept of a career based on personality and character of students can be implemented through technology. This is because the use of technology will make it easier for students to know the characteristics of himself and develop himself.

In this study, we developed an assessment tool SDS or Self-Directed Search, which is the development of the theory of the existing Holland to know the personality and characteristics of a person in the determination of careers. We developed this assessment tool using android application. Following the initial display application to be developed:
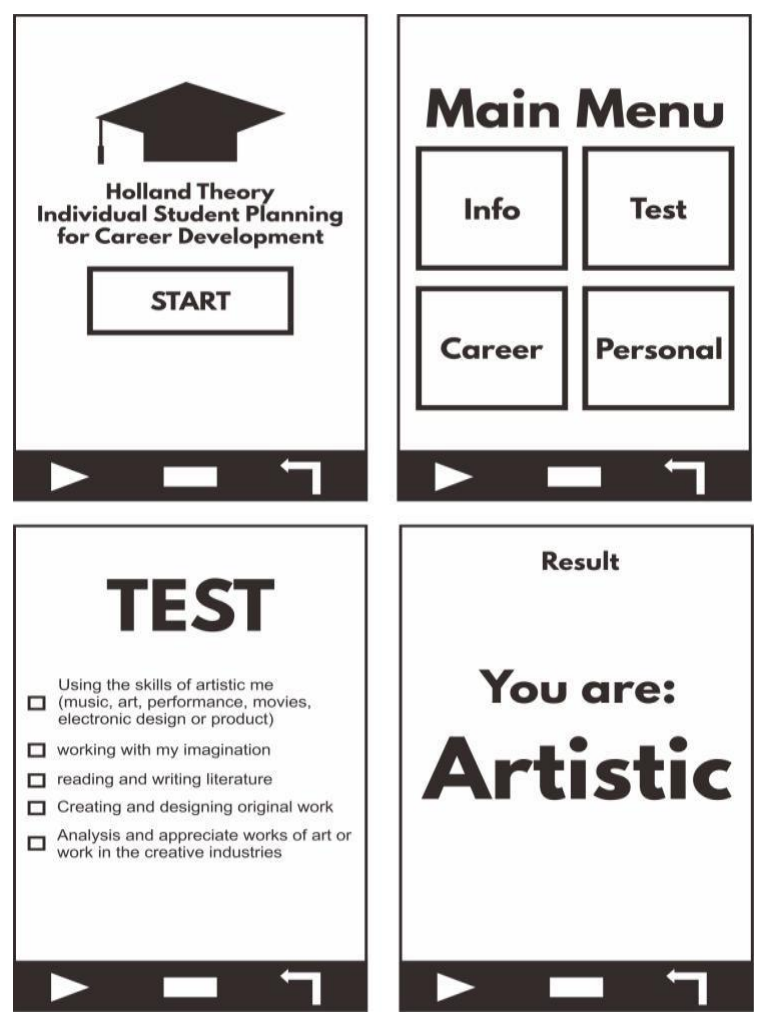

Fig 1. Example Design of Holland Theory Application

This application has several features, among others: info, Test, Personal and Career. In part this info, students were given information regarding the purpose of the application, benefits and associated bit six personalities they'd search. Then the test piece, a part where their questioner SDS which is filled by the students to know the personality of himself. The results of the students' answers will be known when finished filling out questionnaires. Then career, which students are given the job reference herein in accordance with the personality they can. Then the personal section that is the relevant part of the student profile which contains the name, age, gender, and purpose and ideals to be achieved. From here, all the plans were drawn up and was prepared well through this application.

This research is still in the early stages of the design and concept, so we're doing now is developing and reinforcing the concept of the theory of Holland as the basis for the making of applications. It is expected that when these applications can be used, guidance and counselling teacher or school counsellor even though students can use this application as an individual student planning a career in planning.

Based on the above results, we will continue to develop applications that will assist students in planning his career. This application can be expected to media for guidance and counselling teacher or school counsellor to provide individual student planning to students. Thus, students will know his personality, characteristic 
of himself and the student will be directed and assisted in determining the choice of future career. Suggestions and recommendations that will students gain from these applications will assist students in determining the initial step of its future.

\section{CONCLUSION}

In conclusion, this research career planning is important for students. Career selected students will determine its future. Of course, in career planning, students need to plan very well, so what would students choose not to harm themselves or others, and careers that students will choose according to their needs. Teacher guidance and counselling Theory of Holland became one alternative in future students' career planning. In this research, we adopted in Holland's theory of individual student planning, in which the services are expected students can know the characteristics in him and know his personality in which as a platform to make career choices.

Holland's theory has begun to grow, until Holland alone has named assessment tool SDS or Self-Directed Search, to determine the characteristics and personality. We seek to foster SDS application into an android. This was done to provide an easy to use media for guidance and counselling teachers, school counsellors and students in planning and knowing the personality and characteristics so that the characteristics and personality of the students can determine the future of his career. It is expected that these applications can assist students in planning his career.

For the next researcher, the need to manufacture application to determine the initial shape and application usage in the community. Of course, need to pay attention to a variety of things such as the time of manufacture, resource materials, as well as patented models. Thus, for further research when the application own initial form, is expected to test experts and mass trials. Of the trial, will determine how effective applications that have been made previously.

\section{REFERENCE}

[1] Alger, Amanda L. \& Melissa Luke. The School Counselor Perspective: Preparing Students to be College and Career Ready within a Comprehensive School Counseling Program. The Practitioner Scholar: Journal of Counseling and Professional Psychology. 3, 2014.

[2] Anwar, Moh Khoerul. Buku kerja Eksplorasi Karir. Pustaka Pelajar, Yogyakarta, 2016

[3] ASCA. ASCA National Model Implementation Guide: Foundation, Management and Accountability. American School Counselor Association, America, 2016.

[4] Bhakti, Caraka Putra, Muhammad Alfarizqi Nizamuddin Ghiffari, and Swiejti Maghfira Regita. "Strategy of core curriculum to improving student's critical thinking skill." TERAPUTIK: Jurnal Bimbingan dan Konseling 1(3), 176182, ISSN: 2580-2054, DOI: 10.26539/1379, 2018

[5] Brown, Steven D. \& Robert W. Lent. Carrer Development and Counseling: Putting Theory and Research to work Second Edition. John Wiley \& Sons, Inc, America, 2013.

[6] Desmita.Psikologi Perkembangan. Rosda, Bandung, 2010.

[7] Gysbers,Norman C. 2013. Career-Ready Students: A Goal of Comprehensive School Counseling Programs. National Career Development Association: The Career Development
Quarterly 6, September 2013, DOI: 10.1002/j.2161-0045. 2013. 00057.x

[8] Kumara, Agus Ria, and Vivi Lutfiyani. Strategi Bimbingan Dan Konseling Komprehensif Dalam Perencanaan Karir Siswa SMP. G-COUNS Jurnal Bimbingan dan Konseling 1(2). Juni, 2017. ISSN: 2580-6467

[9] Nauta, Margaret M. The Development, Evolution, and Status of Holland's Theory of Vocational Personalities: Reflections and Future Directions for Counseling Psychology. Journal of Counseling Psychology 57 (1), 2010. DOI: 10.1037/a0018213

[10] Ohler, Denise L. \& Edward M. Levinson. using holland's theory in employment counseling: focus on service occupation. journal of employment counselling 49, Desember 2012.

[11] Rezaei, Amene,Amir Qorbanpoor, Teymor AhmadiGatab, Amir Rezaei. Comparative research for personality types of Guilan University physical exercise and counseling students based on Holland theory. Procedia - Social and Behavioral Sciences 30, 2011. DOI: 10.1016/j.sbspro.2011.10.393

[12] Yuen, Mantak, Norman C. Gysbers, Raymond M.C. Chan, Patrick S.Y. Lau and Peter M.K. Shea. Talent development, work habits, and career exploration of Chinese middle-school adolescents: development of the Career and Talent Development Self-Efficacy Scale. High Ability Studies 21(1), June 2010. ISSN: 1469-834X, DOI: 10.1080/13598139.2010.488089 